\title{
The Net generation in times of pandemic: Customers' technology savviness and social media communication impact on customer-based brand equity
}

Joanna Krywalski Santiago, ADVANCE, ISEG - Lisbon School of Economics and Management, Portugal, joannas@iseg.ulisboa.pt

Miguel Pimenta, ISEG - Lisbon School of Economics and Management, Portugal, 151819@aln.iseg.ulisboa.pt

\begin{abstract}
This paper follows the recent areas of interest trucked by Google Trends to investigate the importance of the customers' technological savviness and firm's social media communication at creation of brand equity. A special attention is paid at the so called 'Net generation' and its behavior during COVID-19 pandemic. The data was collected through an online survey distributed in Portugal with the assistance of Qualtrics online survey platform and counted with respondents that had a prior experience in following or engaging with brands on social media. To understand the relationships between Customer Technology Savviness (CTS), firm's Social Media Communication (SMC) and Customer-Based Brand Equity (CBBE), this study applies the Partial Last Squares method of Structural Equation Modelling (PLS-SEM). The results of the multigroup analysis show that customers who used social media more heavily during pandemic denoted a stronger relationship between CTS and CBBE, CTS and SMC and between SMC and CBBE, of which the last was not confirmed in case of customers who made less use of social media since the outbreak of COVID-19 pandemic.
\end{abstract}

Keywords: Technology savviness, social media communication, customer-based brand equity.

\section{Introduction}

In the last decades, the consumer behaviour and mindset have changed, as many consumers now are better informed, qualified and connected. Customers enabled with the 'new digital literacies' are prone to adapt to the changing technologies and are increasingly using social media sites to pursuit information (Menon, 2017; Schivinski \& Dabrowski, 2014). With the increase of those new skills and customer connectivity, customer branding becomes more complex, as there is still a limited understanding of the consequences that social media communication has on "how consumers perceive brands" (Schivinski \& Dabrowski, 2014, p. 1). Ultimately, scholars aim to understand the effects of social media communication on brand management and the customer perceptions of brands (Jalilvand \& Samiei, 2012). Despite this growing attention, the rapid development of new technics and trends, as well as the multidisciplinary of the topic (that can be perceived from the knowledge management and information systems perspective, as well as from 
the marketing and branding point of view aimed at understanding the customer behavior patterns), makes it more difficult to generate 'one rule for all' and leaves many paths for further investigation.

Most recently, the market experienced some more dramatic changes as "the COVID-19 pandemic and the lockdown, as well the social distancing mandates have disrupted the consumer habits of buying as well as shopping" (Seth, 2020, p. 280). Ultimately, customers are re-learning and improvising while being assisted by emerging technologies and channels. Possibly, some of the customer's behavioral patterns will remind altered as the new needs emerged. While indeed one of the most frequently asked questions is whatever the old habits will eventually return, the shifts in customer behaviour are changing the business landscape. Considering the technological developments and the impact of pandemic on customer behaviour, the main objective of this study is to shed some light on how customers' technology savviness and firms' social media communication influence customer-based brand equity, meaning the perception that customers have about brands: their brand associations and the overall brand knowledge that influences the way they respond to the marketing efforts applied (as suggested by Keller, 1993).

The rationale of this study derives from Fishbein's (1979) theory of reasoned action which is used to predict the behavioral intentions or behaviour that leads to a specific outcome (Madden et al., 1992). Those behavioral intentions are the individual attitudes resulting from personal and normative influences (Hale et al., 2002). Additionally, we apply the postulates of generational cohort theory (Ryder, 1985) to examine specifically the Net generation, which is perceived to be the first digitally native generation (Cobres, 2021).

This study adds to the literature by examining customer behaviour and attitudes stimulated by the social media communication and technological savviness and leading to customer brand equity. Although various researchers have conducted empirical studies on factors which are related to the adoption of technology and each time more interest is placed in investigating the effects and technics that can be used via social media, little attention was placed to investigate the influence that the firm's social media communication has on customer perspective of brand equity. Indeed, most of the studies on social media focus on customer-generated content (e.g., Kim, 2012) and only the more recent studies emphasize the importance of well-design and managed firm's social media communication (e.g., Kumar, 2016). Also, while consumer behavior has been the subject of considerable research in the last few years, limited attention has been devoted to understanding consumer behavior and customer brand equity among the different generations. Accordingly, the present study is one of the first attempts to investigate the influence that the net generation technological savviness has on their satisfaction with firm's social media communication and their perception of brand equity, enriching in this way the areas of information technology management, customer relationship management, social media marketing and brand management. It is also one of the first studies examining the customer attitudinal change caused by the current pandemic. Correspondingly, there are three main questions leading this investigation: 1) can customer's technological savviness influence his/hers perception of brand equity?; 2) what is the role and effect of firm social media communication on customer brand equity?; and 3) are there any changes in the customer behaviour and attitudes caused by COVID-19 pandemic?

This study is based on the two methods of investigation. First, the Google Trends search assisted the study and indicated the course of current research on branding and social media 
communication, demonstrating the popularity of the terms and linking the social media with marketing and branding. The second, empirical analysis in which the quantitative data was collected, assisted the hypotheses testing. As the empirical study was conducted almost one year into pandemic, it brought some interesting insights about the costumers' perceptions which vary from what is normally extrapolated by the literature of the field. However, those recent changes start to gain attention from academics and practitioners. Recently, Donthu and Gustafsson (2020) considered the effects of COVID-19 on business and research and collected 13 articles for a special issue of Public Health Emergency Collection, covering different industries, ethical issues, the perspective of employees and changes in consumer behaviour. The authors claimed that although it is not the first world's pandemic, it is still difficult to estimate its impact on customer behaviour and long-term economic or societal consequences, as those aspects were not considered in past studies. Additionally, the limited studies that have been carried, associate the major pandemics with subsequent low returns. Also, as it comes to the role of customer savviness, the research is still limited. This paper intends to fulfill this research gap looking at the recent changes in customer behaviour, customer technology savviness and his/hers perception of brand equity.

This paper is organized in three main sections. First, we present the theoretical background and focus on the main concepts of this study. Then, the results of the Google Trends are exposed, and the study hypotheses are tested and illustrated by Structural Equation Model (SEM). Finally, we discuss the results and present the conclusions in order to answer to the study questions.

\section{Theoretical Background}

\section{Factors Influencing Customer Behavior}

To successfully manage the marketing and branding efforts, organizations tend to understand the customer behaviour and explore the current market factors that influence this behaviour. However, consumer behaviour is a complex matter and predicting how customers will act in a given situation requires a constant observation. According to Jisana (2014), "consumer behaviour means how individuals make decisions to spend their available resources like time, money, effort on consumption of different products and services" (p. 34). Observing the changes in customer behaviour is crucial for the success of marketing campaigns and branding efforts. If able to identify and understand the factors that influence customers, brands have the opportunity to develop a Unique Value Proposition (UVP) that will be expressed in the brand's strategy and marketing campaigns and that can be in line with their target consumers (Ramaya \& Ali, 2016). UVP role is to "make potential consumers aware of the product and its characteristics and to make potential consumers desire it" (Niu \& Wang, 2016, p. 876). According to Yulistiana (2021), UVP can be influenced by brand perceived quality and image which are also crucial to build customer brand equity (Aaker, 1991).

Consumer purchases, brand selection and engagement can be influenced by many external factors and personal traits, such as cultural factors (culture, religion, social class), social factors (reference groups, family, roles and status in the society), personal factors (age, occupation, personality) and psychological characteristics (motivation, perception, believes and attitudes) (Jisana, 2014). The current outbreak of COVID-19 pandemics has also brought not only economic consequences but also have influenced the way customers behave (Donthu \& Gustafsson, 2020). As people have 
been confined and had to learn a new way to work, travel and sometimes even re-organize their lives, they have gained a new perspective. At the same time online communication and online shopping are growing exponentially (Donthu \& Gustafsson, 2020). Some studies noticed that the recent changes led also to more aggressive social media activity influencing the society at large and bringing new topics trending online (Bhattacharya \& Singh, 2020).

Figure 1 exhibits the mental map driving this study, following the customer behaviour and the customer perception of brand equity, influenced by firm's marketing efforts, social media communication, technological savviness and leading to the outcomes of repeat purchases, willingness to pay price premium, customer switching, loyalty and positive 'Word Of Mouth' (WOM). This study focuses particularly on the triangle: technological savviness-social media communication - customer-based brand equity and the next paragraphs will explore those concepts in more depth.

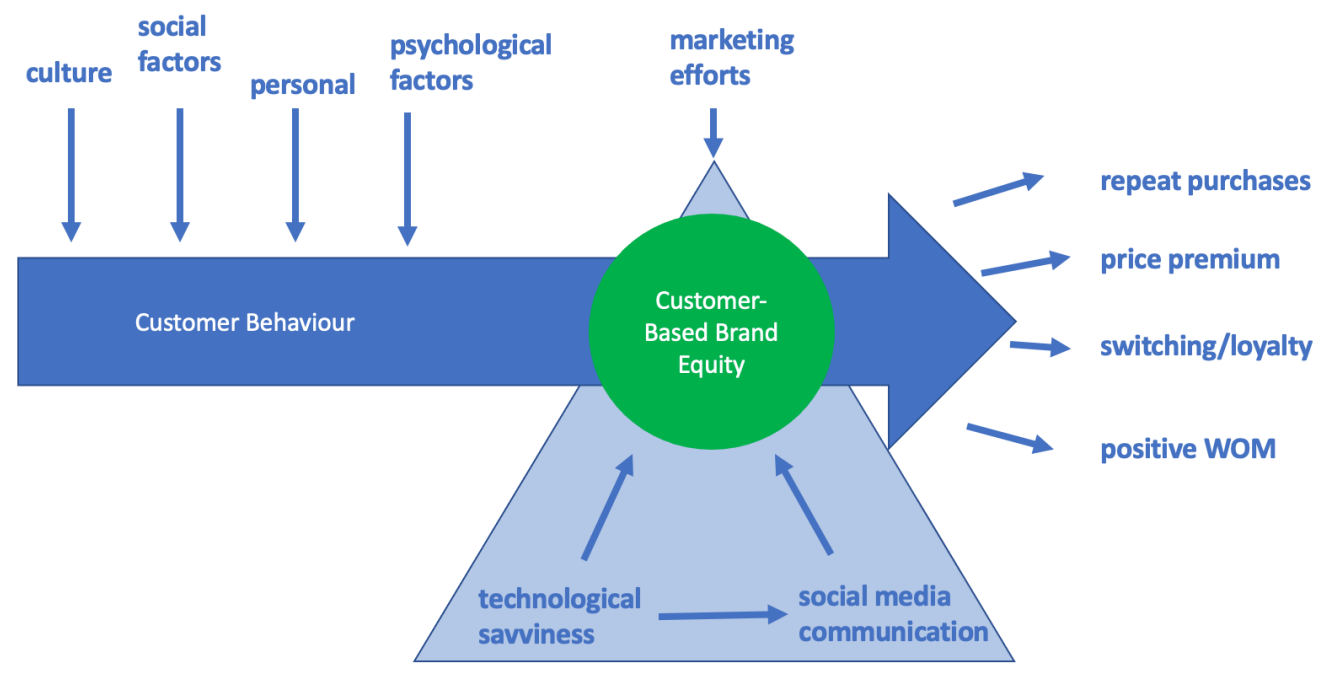

Figure 1. The mental map of customer behaviour

\section{Net Generation}

In accordance with generational cohort theory, different generations represent specific characteristics, as they were born around the same time period and lived through similar situations which shaped their philosophy and makes them to share a connection (Hemlin et al., 2014; Ryder, 1985). Accordingly, those different generations are framing unique cohorts that lived through distinctive formative experiences (Padayachee, 2017). Additionally, as postulated by BakColeman et al. (2021), the group behaviour provides an outline to understand how actions of group members are influenced by the way individuals generate and share information.

In 1998, Tapscott introduced the concept of emerged by technology Net generation. Net generation (also called Net-geners, Y generation, digital natives) is a generational cohort "born between 1980 and the mid-2000s who have grown up constantly surrounded by computer-based and Internet technology" (Kosic, 2018, p. 74). In accordance with the literature, the net generation represents "upper users of technology and assign labels such as tech-savvy, web-savvy, Internet-savvy and 
computer-savvy" (Combes, 2021, p. 3). Interestingly, the same author indicated that the Net generation, although expected to be savvy, seems to be lost in the virtual space despite their almost intuitive knowledge of how to use technology. Similarly, Kosic (2018) combined media literacy and social-emotional literacy of net generation focusing on mental health. The author indicated that the right combination of media and emotional literacy can assist Net-geners to interact, understand and critique the information that they are exposed to, but at the same time it brings new challenges (the author investigated in particular the problem of suicide across Net-geners). Comparably, Jude (2018) indicated that the technical preferences and capabilities of this generation, demands different approach to their teaching and learning. Basing on those recent postulates, in this study we intend to give a closer look at the Net generation and its technological savviness. We claim that those digital skills will also demand different efforts and strategies that the companies make as it comes to their social media communication and branding.

\section{Customer Technology Savviness (CTS)}

Nowadays, the consumers are well-informed and always presume to receive good quality services. The advent of new technologies caused the raise of not only "savvy" but "tech savvy" customers who have both technological and mental aptitudes (Bhattacharya et al., 2015). Following the trend of customer-centricity and the concepts of Net generation or digital natives, the concept of Consumer Technology Savviness (CTS) has recently gained increased interest from the researchers, mostly in the area of e-management and e-marketing (Macdonald \& Uncles, 2007; Menon, 2017). Lankshear and Knobel (2007) explained this change in the mindsets of consumers as 'new literacies' and defined it as "socially recognized ways of generating, communicating and negotiating meaningful content through the medium of encoded texts within contexts of participation in discourses" (p. 224). Indeed, those new abilities have changed the way the customers behave and make their decisions. To fulfill those new expectations and use the Netgeners' abilities firms are persistently announcing new technologies appealing to those tech-savvy customers. Ioanăs and Stoica (2014) claimed that technology gives consumers connectivity and power to explore products, services and brands. Those new literacies are particularly linked to 'digital literacy' (Macdonald \& Uncles, 2007; Lankshear \& Knobel, 2007), as they are more prone to engage in social media and stay digitally accessible (Menon, 2018).

Macdonald and Uncles (2007) identified characteristics that define tech savvy consumers: 1) they are competent and technologically sophisticated; 2) they have some degree of marketing/advertising literacy, 3) they are used to interpersonal and online networking; 4) they are empowered by their self-efficacy; 5) they have high expectations. Additionally, Schivinski and Dabrowski (2014) affirmed that tech-savvy customers are more likely to enhance information they receive from social media and through firm-generated content. Accordingly, those new literacies allow improved social media communication of tech-savvy customers and lead to additional benefits.

The benefits of customer tech savviness are several: it brings improved connectivity and accessibility, as well as it improves firm(brand)/customers relationship. The superior consumer connectivity that is enabled by the technological savviness enables the access of consumers to nodes of information that were previously inaccessible, and enhances horizontal communication 
(Macdonald \& Uncles, 2007). As tech-savvy customers are accessible through multiple digital touch points, organizational brands have more ease to engage with them through social media. Furthermore, it can be expected for tech savvy customers to have a greater engagement (Menon, 2017). In accordance with Kumar et al. (2016), "tech-savvy customers are also more likely to supplement information they receive from firm generated content with other online sources and derive greater benefits from social media engagement thus leading to a greater response to firm generated content" (p. 11). As one of the continuous efforts of brand management is to create a relationship with customers and to differentiate from the competitor brands, thus, customer savviness offers undeniable advantages (Schivinski et al., 2015). Based on this, we hypothesized that: CTS influences the customer-based brand equity (H1) and their overall satisfaction with firm's social media communication (H2).

\section{Social Media Communication (SMC)}

Over the last years, social media have been enjoying a remarkable success, evolving and transforming the ways through which people communicate and connect with others. Due to the rapid entry of social networks into society, companies quickly discovered the potential for using them as marketing or branding tools (Yadav \& Rahman, 2017). Social networks are cheap, easyto-use, scalable technologies based on mobile platforms that allow content sharing (Tsimonis \& Dimitriadis, 2014). These platforms allow brands to communicate with consumers using different forms of communication with a wide reach and low cost, when compared to traditional media (Tsimonis \& Dimitriadis, 2014). Following Kaplan and Haenlein (2010, p. 61), social media can be defined as "a group of Internet-based applications that build on the ideological and technological foundations of Web 2.0, and that allow the creation and exchange of user generated content". This means that social media emerged as a result of the digital evolution and nowadays are both inseparable and inevitable within the online world, not only for individual users, but also for companies (Neti et al., 2011; Weinberg \& Pehlivan, 2011). Indeed, in the literature there is a distinction between firm's social media communication (managed by companies) and usergenerated content (independent from the companies) (eg., Zailskaitè-Jakštè \& Kuvykaitè, 2016). Studies on social media have primarily focused on user generated content but as firms increasingly apply social media tools to engage with customers, more recent studies have attempted to comprehend diverse aspects of firms' engagement via social media (Kumar et al., 2016). Firm's Social Media Communication (SMC) refers to the messages posted by firms, on their official social media pages in aim to develop one-on-one relationships with their customers (Menon, 2017; Poulis et al., 2019). This content must only be shared by the organizations' official social media pages, such as Twitter, Facebook and YouTube pages. The possibility of posting a 'Like' or commenting on these social networking sites can also lead to an increase in positive brand associations that the customers have (Kumar et al., 2016; Menon, 2017; Wan \& Ren, 2017). The objective of the SMC is to increase brand awareness and brand equity, as well as to work as a complement to usergenerated content, through attractive publications that invite users to interact, increasing in this way the sense of belonging and involvement, positive ratings and attitudes (Goh et al., 2013; Schivinski \& Dabrowski, 2016). In addition, brand managers also hope to strengthen ties with loyal consumers, influence consumer perceptions in general, and learn from and about their target audience (Goh et al., 2013; Schivinski \& Dabrowski, 2016). Therefore, one of the benefits that 
effective social media brand communication brings is its positive influence on customer-based brand equity (Schivinski at el., 2015).

In this paper, we focus on firm's social media communication and consider the customer satisfaction with the companies' communication. The growing role of social media and the rapid digital revolution have forced organizations to radically redesign their communication strategies. Companies are increasingly adopting information technology tools that can respond to market changes and bring them closer to their stakeholders, leading them to move away from traditional marketing channels. With this in mind, social media is becoming the easiest way to communicate and capture the attention of consumers who best match the companies' target audience. However, as companies intensify their use of social media, there is growing interest about whether and how their activities are paying off (Colicev et al., 2019; Jayasuriya et al., 2018; Khadim et al., 2014; Menon, 2017; Wan \& Ren, 2017).

There are several benefits that companies expect from social networks: the creation and strengthening of relationships with current and potential customers, easy interaction and ability to better understand customer needs, increased brand awareness, ability to impact certain target audiences in a more precise way, platforms to promote products or services and, finally, companies expect users' engagement and interaction. However, to obtain these benefits, companies need to equip themselves with capabilities that allow them to monitor their activities on the social networks and interact with their communities in a way that has a positive impact and efficiency (Benthaus et al., 2016). According to the literature, there are two approaches for companies to manage their social media platforms and their presence on them: the passive approach and the active approach (Constantinides, 2014). Following the passive approach, the company only uses the social media to gather information about consumers and to 'give them a voice'. By monitoring these platforms, firms are better informed, have access to customers' opinions and are able to detect any problems with products faster than in previous, more traditional ways. By implementing the active approach, the company can make use of various techniques with the ultimate goal to deliver the consumer a more personalized experience. Companies can actively use social media as public relations platforms or product/service promotion tools, use them to work with digital influencers as brand promoters or ambassadors, allow product customization and encourage users to contribute with product analysis, promotion proposals and future innovation, thus achieving positive contact with the public (Benthaus et al., 2016; Constantinides, 2014).

While considering the Net generation and the use of social media communication, there are studies indicating that this generation is not necessary 'net savvy'. Lorenzo and Dziuban (2006) claimed that although this generation "may have never known life without the Internet, they are not necessarily net savvy. Exposed to huge quantities of information on the Web-in text, audio, image and video formats - sorting valid information from misinformation is a constant challenge" (p. 290). Accordingly, we find it important to investigate if the Net generation is able to extract the firm and brand content and relate it to other brands' social media communication.

\section{Consumer-Based Brand Equity (CBBE)}

Currently, companies make an immense effort to promote their brand and apply additional efforts to build a strong relationship with the consumer, as well as to provide the customer experiences 
ensuring additional value. Accordingly, companies focus on increasing brand equity (Datta et al., 2017; Troiville et al., 2019).

Brand equity consists of the 'added value' that a brand has on a given product and which gives this perceived usefulness and desire, which without the brand the product would not have (Troiville et al., 2019; Veloutsou \& Guzmán, 2017). In other words, the power of the brand is influenced by brand knowledge that the customers possess (Keller, 1993; Troiville et al., 2019). Brand knowledge, in turn, is composed of recognition and remembrance (Keller, 1993). Also, investing in customer loyalty is key for building brand equity, and the results will pay off on the long run once brand equity increases the company's value (Aaker, 1991). Brand equity can be developed through advertising (Lebar et al., 2005), triggering consumers' memory when they have established a link with the brand, associating the product/service with the specific brand (Keller, 1993).

Although, not the most recent ones, the two fundamental visions of brand equity are those of Aaker (1991) and Keller (1993) who started the debate of Customer-Based Brand Equity (CBBE) and whose conceptualization is still widely used in studies on customer brand equity. Aaker (1991) defined brand equity from the consumer's perspective, establishing that it consists in the combination of several brand assets and liabilities that are linked to the brand's name and symbol, either increasing or decreasing the value of the brand's products or services and providing value to the firm and to its customers. Furthermore, the author also indicated the assets that must be considered, more precisely: brand loyalty, brand name awareness, perceived brand quality, brand associations, and in addition to the perceived quality or the brand image, and other proprietary brand assets, such as patents, trademarks and channel relationships. Keller (1993), on the other hand, claimed that $\mathrm{CBBE}$ is the "differential effect of brand knowledge on consumer response to the marketing of the brand" (p. 2). In other words, CBBE compares consumers' reactions to the same marketed product, but from different brands: one is associated to a specific brand, while the other is associated to a fictitiously named or unnamed brand. Keller (1993) had also claimed that in order to achieve long-term results, marketers must rely on the brand knowledge that was previously provided by the short-term marketing efforts. It is noteworthy to mention that brand knowledge refers to two main aspects of the brand itself, namely to brand awareness and brand image (Severi \& Ling, 2013). More recently, Keller (2016) indicated the need to understand the digital effects in branding and how to use the new digital technics to manage customer relations, mostly the area of digital communications as is can allow companies to "develop a dialogue and forge stronger brand ties" (p. 11). Keller (2016) indicated that indeed the digital effect in branding is "a hugely important area not addressed in the original CBBE article" (p. 11). Keller (2016) further indicated that there is a need to consider the new customer and firm capabilities. Following this indication, in this study we intend to investigate the customer tech savviness and social media communication effects on customer brand equity.

\section{The Relationship Between SMC and CBBE}

This paper is grounded in the CBBE perspective of brand equity as proposed by Aaker (1991) and Keller (1993) and follows the more recent Algharabat et al. (2019) postulates according to which "social media plays a significant role in the creation of brand equity" (p. 4). This conceptualization 
goes in pair with earlier Yoo et al. (2000) suggestions that emphasized brand communication as an important factor that enhances brand equity. Additionally, there is a growing research interest in the role that social media plays in brand equity creation. Bruhn et al. (2012) pioneered the studies on social media and brand equity relationship and considered the impact of social media brand communication while comparing it to traditional media. The results of their study showed that both traditional and social media communication had a strong impact on brand equity but interestingly, traditional media seemed to have a stronger impact on brand awareness while social media communications strongly influenced brand image. More recently, Alam and Khan (2019) considered the role of firm's social media communication and claimed that "businesses are actively present on social media platforms so that they can understand how consumers are responding to anything related to their brands" (p. 54). Also, Schivinski and Dabrowski (2016) claimed that social media communication becomes more important that the traditional communication, as there are the customers themselves who are turning away from the traditional communication means (like for instant television or magazines). Mostly, the young generations (like the Net generation, or Millennials \& Z generation) are the ones whose behaviour is more influenced by social media (Duffett, 2017). Similarly, in their study on the impact of social media communication on brand loyalty and purchase intention among Generation Y, Balakrishnan et al. (2014) indicated that "social media marketing medium has become an important marketing tool to reach emerging younger generation consumers" (p. 177). Accordingly, social media communication should be considered by brand managers as it enables faster and more effective campaigns. Accordingly, our third hypothesis is stated: there is a positive relationship between social media communication and customer-based brand equity (H3).

\section{Customer Behaviour During the COVID-19 Pandemic}

As we know, customer behaviour is affected by personal end external traits, tendencies or happenings. Accordingly, one of the purposes of this study is to contribute to an understanding of the possible impacts of the COVID-19 pandemic on consumer behaviour, specifically on the customers' attitude towards firms' social media communication and the perception of brand equity. In their recent study Eger et al. (2021) claimed: "the global COVID-19 pandemic has seriously affected societies and economics around the world and has hit various sectors of society in different ways. This unprecedented situation has several consequences for the everyday life of consumers and has dramatically changed how businesses act and consumers behave" (p. 1). As the impact of the current pandemic on business is notable, Journal of Business Research have recently released a special issue entitled: "Effects of COVID-19 on business and research" (Donthu \& Gustafsson, 2020). In accordance with Donthu and Gustafsson (2020), it is challenging to estimate the longterm effects of pandemics. The authors claimed: "although society has been hit by several pandemics in the past, it is difficult to estimate the long-term economic, behavioral, or societal consequences as these aspects have not been studied to a great extent in the past" (p. 284). Also, and as postulated by Sheth (2020), consumer behavior during pandemics changed as people adopted new routines. Since people have been confined to their homes, one of the consequences of the lockdowns is the increase in the usage of Internet and social media (Donthu \& Gustafsson, 2020). Indeed, in accordance with Donthu and Gustafsson (2020), when people feel lonely, they tend to use social media more intensively and sometimes they even prefer to use social media than 
to have a physical interaction as "the current situation has made social media the main mode of contacting or socializing with others" (p. 284). Very recently, Rather (2021) revisited customer behaviour and conducted a study on impacts of tourism-based social media, risk perception and fear on tourist's attitude in the wake of COVID-19 pandemic. The study findings showed a significant positive effect that social media has on customer brand engagement during COVID-19 outbreak. Additionally, the results confirmed that customer social media engagement have positive effects on brand co-creation.

Based on the above, we hypothesized that customers' change of behaviour (more intense use of social media, preference to buy online, as well as a changed perception of a chosen brand) during pandemic influence the relationship between SMC and CBBE (H4).

\section{Methodology and Results}

\section{Google Trends in Academic Research}

This paper follows the recent trends to investigate the importance of social media communication at creation of brand equity in the perspective of customers' technological savviness and applies two methods of research: first the Google Trends to additionally validate the importance of the subject under investigation, and then a survey, to empirically validate the study and to test the proposed hypotheses. Google Trends is an online tool that offers data based on users' search behavior within Google Search and helps to visualize the current trends. Data provided in this way is quite simple - the tool shows how frequently a particular search term was entered in comparison with other search terms in different regions and languages (the tool facilitates a global search since 2004). Despite this simplicity, since its introduction in 2004, the tool has become a quite popular source of data for academics and practitioners. It was estimated that searches on Google Trends reached 2 trillion in 2016 (Sullivan, 2016). More recently, Jun et al. (2018) analyzed 657 research studies (originating form SCOPUS database) which have utilized Google Trends, and noticed that the platform is a popular information source for marketing managers and academic researchers.

Interestingly, the first academic study using this tool was the analysis on influenza spread which demonstrated that Google Trends traced and predicted the spread earlier than the Centers for Disease Control and Prevention (Ginsberg et al., 2009). Since then, many other academic papers used the statistical dataset provided by the tool (e.g., Choi \& Varian, 2009; Vaughan \& Chen, 2015). In accordance with Jun et al. (2018), Google Trends, and other sources of Big Data, have become important tools to aid recognizing the current trends and to identify new areas for research. In this study, we explore the search terms and their tendencies trucked by Google Trends since 2004 which is the year when the term Web 2.0 was introduced. Particularly, we assess the popularity of 'social media communication' and 'brand equity' and tend to classify the emerging topics and areas of interest. Table 1 (below) summarizes the Google Trends search ailment.

The aim of this search was to compare the interest over time of 'social media communication' (in blue) and 'brand equity' (in orange) shown in Figure 2 (below). 
Table 1. Detailed Conditions of the Google Trends Search

\begin{tabular}{|ll|}
\hline Description & Conditions/Results \\
\hline Initial Search Expression & Google Trends \\
Search field & 'social media communication, 'brand equity' \\
& $\begin{array}{l}\text { term, topic, worldwide, all categories, 2004-present, } \\
\text { web search, interest over time, compare, interest by } \\
\text { subregion, related topics, related queries }\end{array}$ \\
$\begin{array}{l}\text { Search period } \\
\text { Search date } \\
\text { Total number of months } \\
\text { searched }\end{array}$ & $\begin{array}{l}\text { 2004-2021 } \\
\text { 30th January 2021 }\end{array}$ \\
\hline
\end{tabular}

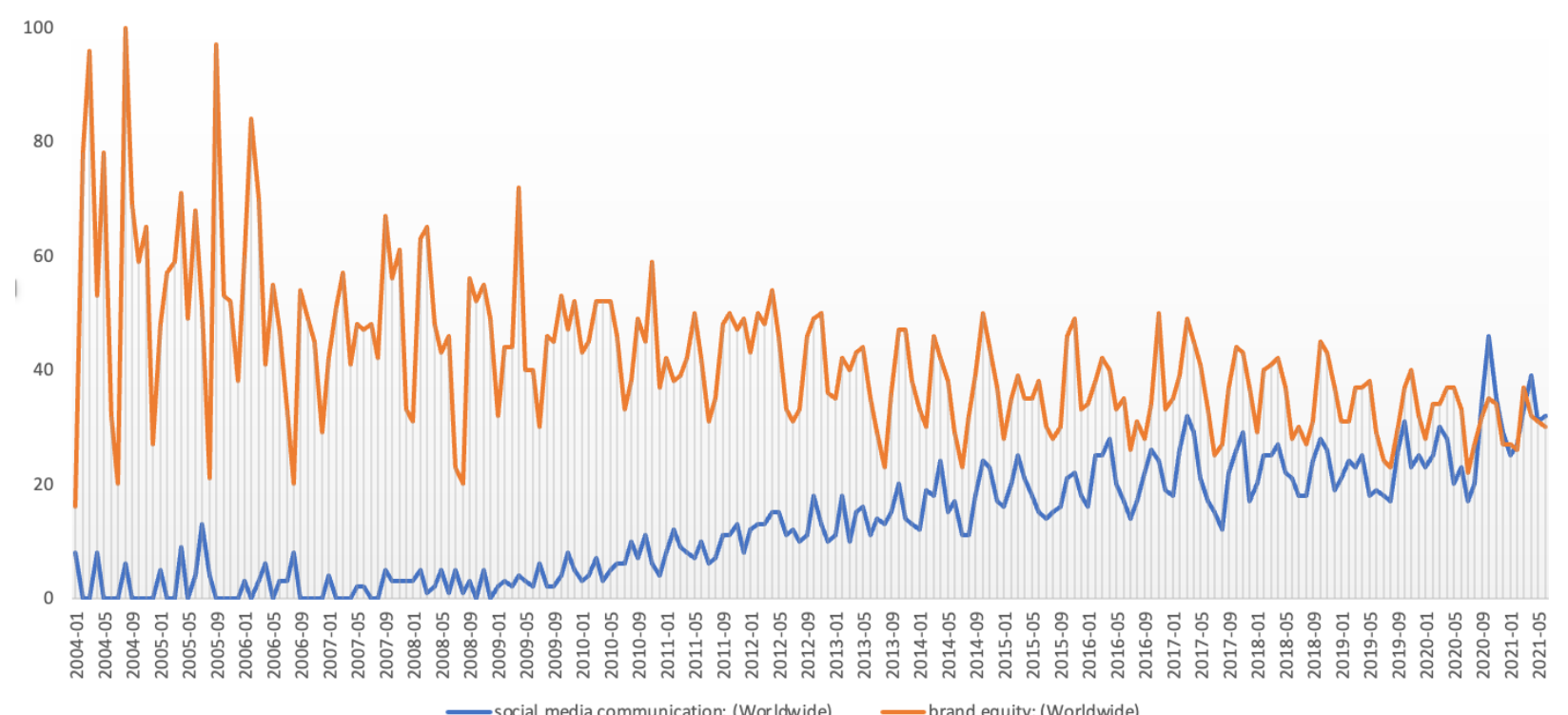

Figure 2. Interest Over Time

The most popular topics are designated as 'top' and they are scored on a relative scale, where a value of 100 is the most commonly searched topic and a value of 50 is a topic searched half as often as the most popular term (Google, 2020). Based on this, it was noticed that the term 'brand equity' initially was much more popular in terms of search (2004-2015). As it comes to 'social media communication', the term is still far from its possible popularity peak (oscillates within the value of 25-50 after 2015). This observation can be related to the historical development of both areas. Table 2 shows the 'top' topics indicated by Google Trends. 
Table 2. TOP - The Most Popular Topics

\begin{tabular}{lr|lr}
\hline \multicolumn{1}{c|}{$\begin{array}{c}\text { Related to 'social media } \\
\text { communication' }\end{array}$} & \multicolumn{1}{c}{ Related to 'brand equity' } \\
social media and & 100 & brand equity & marketing \\
communication & 32 & marketing & 100 \\
what is communication & 31 & what is brand & 99 \\
what is media & 30 & what is brand equity & 79 \\
what is social media & 25 & brand definition & 76 \\
social marketing & 25 & equity definition & 61 \\
marketing communication & 25 & brand equity model & 60 \\
social media marketing & & customer brand equity & 58 \\
& & customer equity & 50 \\
& & brand value & 50 \\
& & branding & 49 \\
& equity meaning & 41 \\
& brand equity meaning & 39 \\
& brand equity in & 38 \\
& marketing & 36 \\
\hline Social media communication: & Brand equity: (1/1/04 - 1/30/21, \\
$(1 / 1 / 04-1 / 30 / 21$, Worldwide) & & Worldwide) \\
\hline
\end{tabular}

Additionally, we have verified the popularity of the term 'COVID-19 pandemic' - starting from February 2020 (the moment when the lockdowns have initiated in Europe) to July 2021 worldwide (Figure 3a) and in Portugal (Figure 3b).

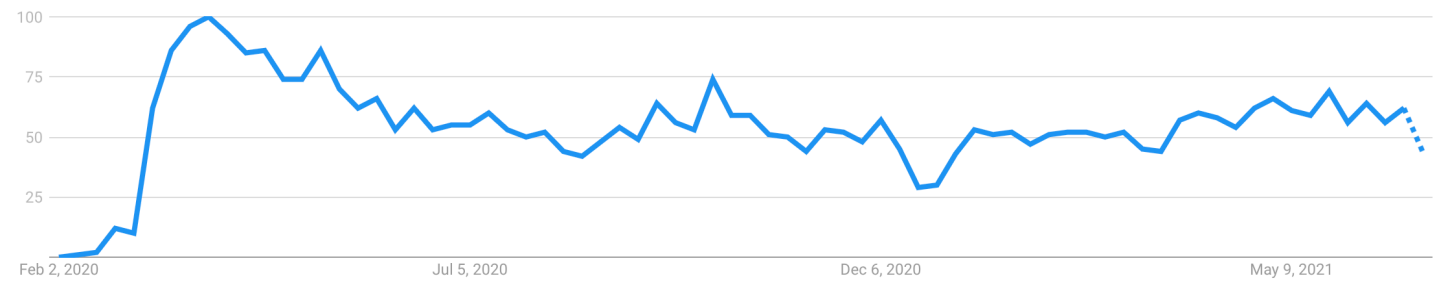

Figure 3a. 'COVID-19 pandemic' - popularity of the term from February 2020 to July 2021 worldwide.

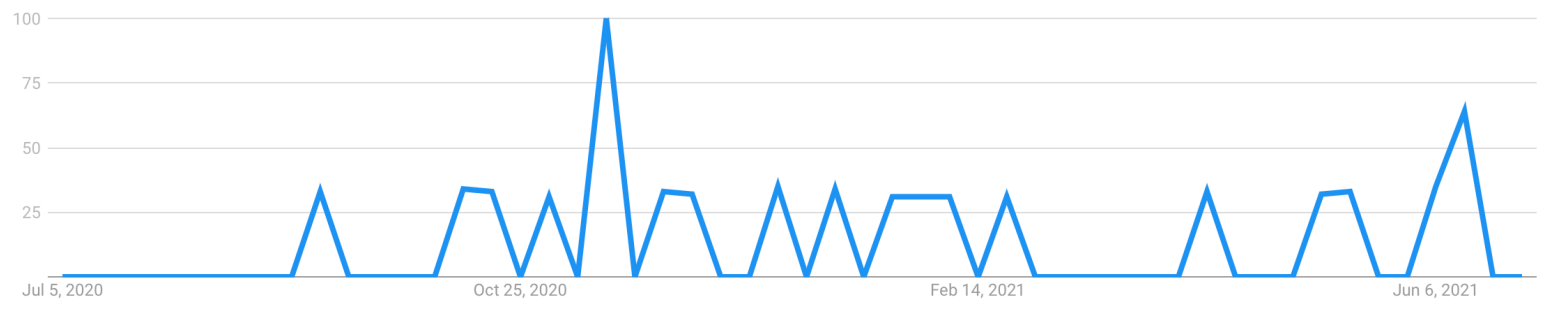

Figure 3b. 'COVID-19 pandemic' - popularity of the term from February 2020 to July 2021 in Portugal. 


\section{Survey Study}

The data was collected through an online survey by questionnaire distributed in Portugal. We have chosen this instrument as it is an economical way to collect data and carries many advantages: speed, uniformity, wide coverage, etc. It also allows to collect quantitative data which were adequate to test the proposed hypothesis. As for the questionnaire design, it was initiating with a filter question to inquire if respondents were active users of social media - only the respondents that confirmed could carry on with the questionnaire as they were the target of this study (that is one of the reasons why some answers were lost from the total number of responses). Then respondents were also asked to indicate which are the social media of their preference and if they follow any brand on social media. In a way to ensure the consistency of the findings, respondents were asked if they follow on social media any brand related to electronics and new technologies (the main selections were: Apple, Samsung, Huawei and Microsoft). From this moment, the focus of the questionnaire was on the specific brand indicated by respondents. The next section of the questionnaire was based on the Likert scales aimed to ascertain the perceived quality of the social media content created by the company (and that respondents followed on social media), the brand equity of a selected brand and technology savviness. In the last part of the questionnaire respondents were asked some personal details, including their education, income, age and sex. They were also asked if their professional situation and income have changed during the pandemic.

\section{Measurement of Variables}

All of the scales used in this study were validated in previous research and used seven-point Likert scales ( 1 = 'strongly agree', 7 = 'strongly disagree'). SMC was measured by four-items with 7point Likert scale proposed by Schivinski and Dobrowski (2016) and focusing on the satisfaction with the company's social media communication, attractivity of the communication, as well as on the comparation to other firms' social media communication (see Appendix). To measure CTS, we used the three-item with 7-point Likert scale proposed by Menon (2017) and measuring the preference of reading the information on Internet, interests in new technology and easiness to locate the information on Internet. Finally, the CBBE was measured by four-items with 7-point Likert scale validated by Yoo et al. (2000) and measuring the customer brand preference as compared to competitive brands. All the scales were translated to Portuguese and then back to English by two translators. Table 3 shows the definitions of the variables of this study and indicated the sources of the scales applied in this study.

Additionally, the respondents were asked if they social media communication increased, if they prefer to shop online and if their perceptions related to the specific brand have changed during COVID-19 pandemic. Here a four-items with a five-point Likert scale was applied and measured specifically: "My view on [Brand] changed during the confinement period", "My social media activity increased during the confinement period", "My online purchases increased during the confinement period", "Now I prefer to shop online". Those items were developed specifically for this study and as they require further validation, we have only used them to create clusters applied in multi-group analysis. 
Table 3. Variables of the Study

\begin{tabular}{|c|c|c|c|}
\hline Variable & Definition & Reference & Scale \\
\hline $\begin{array}{l}\text { Firm's Social } \\
\text { Media } \\
\text { Communication } \\
\text { (SMC) }\end{array}$ & $\begin{array}{l}\text { Social media are defined as online resource designated to } \\
\text { facilitate engagement. } \\
\text { Firm's SMC can be defined as the communication of information } \\
\text { (of any kind) created by companies and shared directly on their } \\
\text { official social media platforms. The objective of the SMC is to } \\
\text { increase brand awareness and brand equity and work as a } \\
\text { complement to user-generated content, through attractive } \\
\text { publications that invite the interaction of users, brand fans, } \\
\text { increasing the sense of belonging and involvement, as well like } \\
\text { evaluations and positive attitudes. }\end{array}$ & $\begin{array}{l}\text { Bishop, } 2019 \\
\text { Schivinski \& } \\
\text { Dabrowski, } 2016\end{array}$ & $\begin{array}{l}\text { 7-point } \\
\text { Likert }\end{array}$ \\
\hline $\begin{array}{l}\text { Customer } \\
\text { Technology } \\
\text { Savviness (CTS) }\end{array}$ & $\begin{array}{l}\text { Technologically savvy customers are the ones who have both } \\
\text { technological and mental aptitudes. Organizations are constantly } \\
\text { introducing new technologies that interest consumers with high } \\
\text { technological skills. This type of consumer is accessible through } \\
\text { various digital channels and, as companies interact with this type } \\
\text { of consumer, they expect them to take the reciprocal attitude of } \\
\text { producing responses and interactions on social networks. }\end{array}$ & Menon, 2017 & $\begin{array}{l}\text { 7-point } \\
\text { Likert }\end{array}$ \\
\hline $\begin{array}{l}\text { Costumer-Based } \\
\text { Brand Equity } \\
\text { (CBBE) }\end{array}$ & $\begin{array}{l}\text { The 'added value' that a brand has on a given product and which } \\
\text { gives this perceived usefulness and desire, which without the } \\
\text { brand the product would not have. } \\
\text { The core of customer-based brand equity is the brand knowledge } \\
\text { composed by brand awareness (brand recall and recognition) and } \\
\text { brand image expressed by unique and favourable brand } \\
\text { associations. }\end{array}$ & $\begin{array}{l}\text { Yoo et al., } 2000 \\
\text { Keller, } 2016\end{array}$ & $\begin{array}{l}\text { 7-point } \\
\text { Likert }\end{array}$ \\
\hline
\end{tabular}

\section{Data Collection}

The survey instrument was distributed predominantly with the use of social media and e-mail, therefore, using a non-probabilistic convenience sample (Malhotra \& Briks, 2006). First, the questionnaire was pre-tested with 15 respondents. Then, the actual survey was activated in September 2020 with the assistance of Qualtrics online survey platform and counted with 321 responses. The final sample was composed of 268 respondents, as all incomplete questionnaires were excluded from the analysis.

\section{Descriptive Statistics of Study Participants}

As considering the sample characterization (see table 4), of the 268 individuals whose answers were considered valid, about $54.5 \%$ were female and the remaining $45.5 \%$ were male. All respondents were adults, aged between 18 and 64 years, with the most of individuals falling in the age group of $18-29$ years old (58.5\%). Accordingly, the sample counted with 229 answers $(84.5 \%)$ from the respondents belonging to net generation. Regarding academic training (education), most respondents had a bachelor's degree (55.9\%), followed by those who had completed secondary education $(29 \%)$. In terms of professional status, almost half of respondents were students $(49.7 \%)$ and none of the respondents indicated to be unemployed or retired. The monthly income of most of the respondents (54\%) oscillates between 499 and $999 €$. Additionally, as it comes to the changes in professional situation caused by the recent COVID-19 pandemic, more than half of the respondents (54\%) have not experienced any change. Finally, as it comes to income, $48 \%$ of the respondents indicated to receive a reduced income as a result of pandemic. 
Table 4. Descriptive Statistics of Study Participants

\begin{tabular}{|c|c|c|c|}
\hline Indicator & Answers & $\begin{array}{l}\text { Number of } \\
\text { Responses }\end{array}$ & Percentage \\
\hline \multirow[t]{2}{*}{ Sex } & Male & 122 & $45.5 \%$ \\
\hline & Female & 146 & $54.5 \%$ \\
\hline \multirow[t]{4}{*}{ Age } & $18-29$ & 157 & $58.5 \%$ \\
\hline & $30-45$ & 72 & $26.9 \%$ \\
\hline & $46-64$ & 39 & $14.6 \%$ \\
\hline & 65 and more & - & - \\
\hline \multirow[t]{5}{*}{ Education } & Primary & - & - \\
\hline & Secondary & 78 & $29 \%$ \\
\hline & Bachelor's Degree & 150 & $55.9 \%$ \\
\hline & Master's Degree & 39 & $14.6 \%$ \\
\hline & Other & 1 & $0.5 \%$ \\
\hline \multirow[t]{6}{*}{ Occupation } & Employed working for others & 75 & $28 \%$ \\
\hline & Employed working as freelancer & 60 & $22.3 \%$ \\
\hline & Student & 133 & $49.7 \%$ \\
\hline & Unemployed & - & - \\
\hline & Retired & - & - \\
\hline & Another situation & - & - \\
\hline \multirow{5}{*}{$\begin{array}{l}\text { Monthly } \\
\text { income }\end{array}$} & $0 €-499 €$ & 35 & $13 \%$ \\
\hline & More than $499 €$ up to $999 €$ & 145 & $54 \%$ \\
\hline & More than $999 €$ up to $1499 €$ & 42 & $15.7 \%$ \\
\hline & More than $1499 €$ up to $2000 €$ & 32 & $11.9 \%$ \\
\hline & More than $2000 €$ & 14 & $5.4 \%$ \\
\hline
\end{tabular}

\section{Measurement Model Assessment}

To understand the relationships between customer technology savviness, firm's social media communication and customer-based brand equity, this study applies the partial last squares method of structural equation modelling (PLS-SEM) with the support of the SmartPLS 3.3.3 software. The choice of using PLS methodology was motivated by the advantages that it carries: it works well with small sample size and constructs may be measured by less than four items, which is not possible with SEM. PLS is a rigorous technique that uses latent variables and cause-and-effect relationships which allows testing the theoretical component-based model presented in this study. This multivariate analysis technique has become popular among researchers and it has been already adopted in prior research on online user behaviour (Lee \& Chen, 2010).

The measurement model was assessed in terms of the reliability of items (Cronbach's alpha >0.7), indicator reliability (reflective indicator loadings $>0.5$ ), internal consistency (assessed using composite reliability, CR $>0.7$ ), convergent reliability (assessed using average variance extracted, AVE $>0.5$ ), and discriminant validity (cross loading criterion) as indicated by Chin (2010). Table 5 describes the indicator loadings, the Crombach's alpha, consistent reliability (Rho_A), the composite reliability (CR) and the average variance extracted (AVE) of each latent variable.

The results support the reliability of the measurement indicators. We decided not to remove CTS because its reliability coefficient was very near the cut-off point (of the indicated 0.7 ). As the average variance extracted (AVE) of each indicator is grater that the expected minimum it ensures convergent validity (in this way following the Fornell and Larcker (1981) criterion of convergent validity). While considering the composite reality (CR) values, it was observed that they are also 
higher than the recommended minimum of 0.7 (Gefen et al., 2000), in this way demonstrating that all constructs represent acceptable internal consistency.

Table 5. Measurement Model Table.

\begin{tabular}{|c|c|c|c|c|c|c|}
\hline Variables & Items & $\begin{array}{c}\text { Outer } \\
\text { loading }\end{array}$ & $\begin{array}{c}\text { Cronbach's } \\
\text { Alpha }\end{array}$ & rho_A & $\begin{array}{c}\text { Composite } \\
\text { Reliability } \\
\end{array}$ & $\begin{array}{c}\text { Average Variance } \\
\text { Extracted (AVE) }\end{array}$ \\
\hline \multirow[t]{4}{*}{ CBBE } & CBBE1 & 0.939 & 0.940 & 0.954 & 0.957 & 0.848 \\
\hline & CBBE2 & 0.843 & & & & \\
\hline & CBBE3 & 0.927 & & & & \\
\hline & CBBE4 & 0.969 & & & & \\
\hline \multirow[t]{3}{*}{ CTS } & CTS1 & 0.706 & 0.696 & 0.728 & 0.834 & 0.629 \\
\hline & CTS2 & 0.918 & & & & \\
\hline & CTS3 & 0.737 & & & & \\
\hline \multirow[t]{4}{*}{ SMC } & SMC_Attraction & 0.957 & 0.951 & 0.999 & 0.963 & 0.869 \\
\hline & SMC_Expectations & 0.962 & & & & \\
\hline & SMC_Performance & 0.848 & & & & \\
\hline & SMC_Satisfaction & 0.957 & & & & \\
\hline
\end{tabular}

As it comes for the discriminant validity, Table 6 shows the indicator item cross loading and table 7 presents the discriminant validity criterion as postulated by Fornell and Larcker (1981). In accordance with data, the cross-loadings are lower than outer loadings in all the metrics. Similarly, the square root of AVE is greater than the aggregated value of all correlations with other constructs what confirms the discriminant validity of the measurement scales applied in this study.

Table 6. Indicator Item Cross Loading

\begin{tabular}{llll} 
& CBBE & CTS & SMC \\
\hline CBBE1 & $\mathbf{0 . 9 3 9}$ & 0.550 & 0.081 \\
CBBE2 & $\mathbf{0 . 8 4 3}$ & 0.422 & 0.110 \\
CBBE3 & $\mathbf{0 . 9 2 7}$ & 0.552 & 0.178 \\
CBBE4 & $\mathbf{0 . 9 6 9}$ & 0.589 & 0.144 \\
CTS1 & 0.546 & 0.706 & -0.085 \\
CTS2 & 0.522 & 0.918 & 0.245 \\
CTS3 & 0.282 & 0.737 & 0.403 \\
SMC_Attraction & 0.142 & 0.238 & $\mathbf{0 . 9 5 7}$ \\
SMC_Expectations & 0.174 & 0.234 & $\mathbf{0 . 9 6 2}$ \\
SMC_Performance & 0.073 & 0.099 & $\mathbf{0 . 8 4 8}$ \\
SMC Satisfaction & 0.101 & 0.224 & $\mathbf{0 . 9 5 7}$ \\
\hline
\end{tabular}


Table 7. Discriminant Validity (Fornell \& Larcker Criterion)

\begin{tabular}{lllc} 
& CBBE & CTS & SMC \\
\hline CBBE & $\mathbf{0 . 9 2 1}$ & & \\
CTS & 0.579 & $\mathbf{0 . 7 9 3}$ & \\
SMC & 0.140 & 0.227 & $\mathbf{0 . 9 3 2}$ \\
\hline $\begin{array}{l}\text { *The diagonals are Square Root of the AVE and indicates the highest in } \\
\text { any column or row }\end{array}$ & & \\
\hline
\end{tabular}

\section{The Structural Model}

Figure 4 exhibits the structural model in which the beta values of all coefficients are marked together with the outer model loadings and the $\mathrm{R}^{2}$ adjusted for the dependent variables.

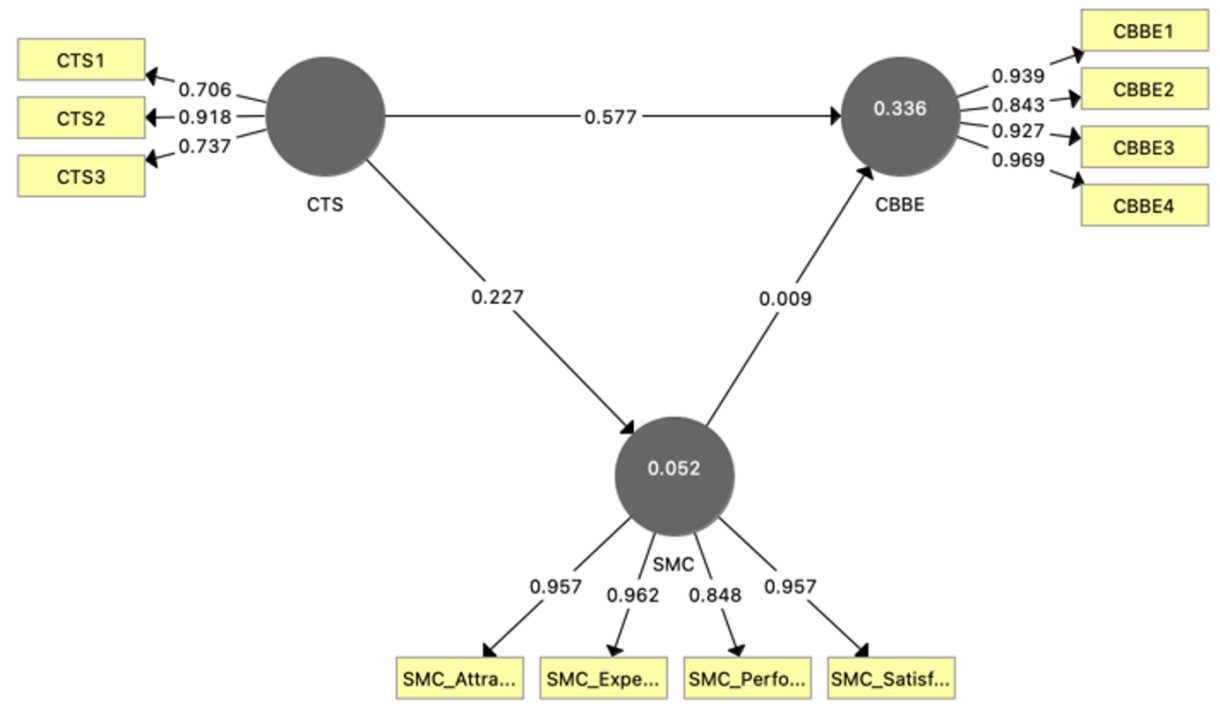

Figure 4. The PLS algorithm model

Table 8. The Algorithm Model Fit

\begin{tabular}{lrr} 
& R Square & \multicolumn{1}{c}{ R Square Adjusted } \\
CBBE & 0.336 & 0.326 \\
SMC & 0.052 & 0.045 \\
\hline SRMR & 0.091 & \\
d_ULS & 0.808 & \\
d_G & 0.362 & \\
Chi-Square & 280.406 & \\
NFI & 0.925 & \\
\hline rms Theta & 0.271 & \\
\hline
\end{tabular}


Table 8 represents the estimated model fit. As the Standardized Root Mean Square Residual (SRMR), which is a measure of the approximate model fit, is lower than .10, we can assume that the model has a good fit (Henseler et al., 2014).

\section{Hypotheses Testing: Bootstrapping Direct Effect Results}

The PLS-SEM uses a non-parametric bootstrapping procedure that artificially generates several samples from the input data, with a significance level of 5\% (Hair et al., 2014). This technique allows us to understand whether, basing on the original sample, it is possible to extrapolate a much larger sample and determine whether the study would have a similar result considering this larger sample. A bootstrapping analysis with a resampling of 5,000 interactions was used in this study in order to calculate the t-values that assess the effects of relationships between hypotheses. It is assumed that if $\mathrm{t}$-value $>1.96$ and $\mathrm{p}$-value $<0.5$ that the hypothesis has the acceptable statistical significance (Chin, 1998). Table 9 presents the means, standard deviations, $t$ statistics and p-values of the outer loadings after running the bootstrapping (with the confidence of 95\%). For the tested models almost all of the outer model loadings are significant (with the exception of EBEEco2).

Table 9. The Outer (Measurement) Model Quality

\begin{tabular}{lccccc} 
& $\begin{array}{c}\text { Original } \\
\text { Sample (O) }\end{array}$ & $\begin{array}{c}\text { Sample Mean } \\
(\mathrm{M})\end{array}$ & $\begin{array}{c}\text { Standard } \\
\text { Deviation } \\
(\text { STDEV) }\end{array}$ & $\begin{array}{c}\text { T Statistics } \\
(|\mathrm{O} / \mathrm{STDEV}|)\end{array}$ & P Values \\
\hline CTS $>$ CBBE & 0.577 & 0.587 & 0.065 & 8.913 & 0.000 \\
CTS $>$ SMC & 0.227 & 0.236 & 0.11 & 2.063 & 0.039 \\
SMC $>$ CBBE & 0.009 & 0.008 & 0.086 & 0.102 & 0.918 \\
\hline
\end{tabular}

\section{Multi-Group Analysis}

An additional multi-group analysis was conducted based on the created clusters amount of use of social media communication during COVID-19 pandemic as a splitting variable intending to support H4 (Figure 5). In order to perform the multi-group analysis, first a cluster analysis was conducted (assisted by SPSS). After the first visual clustering using the hierarchical clustering technique, the K-means clustering method was applied to divide the dataset into a small number of clusters. Afterwards, a partial least squares multigroup analysis was performed to assess subsamples' differences.

The multigroup analysis is significant. The results of the multigroup analysis show changes in the relationship's strength and signs. For customers who use social media more heavily during pandemic, there is a stronger relationship between CTS and CBBE (path coefficient $=0.565$ ), between CTS and SMC (path coefficient=0.338) and between SMC and CBBE (path coefficient $=0.197$ ). Interestingly, the item with lower than previously loading is CTS1: "I prefer to read information on the internet than on in a brochure". 


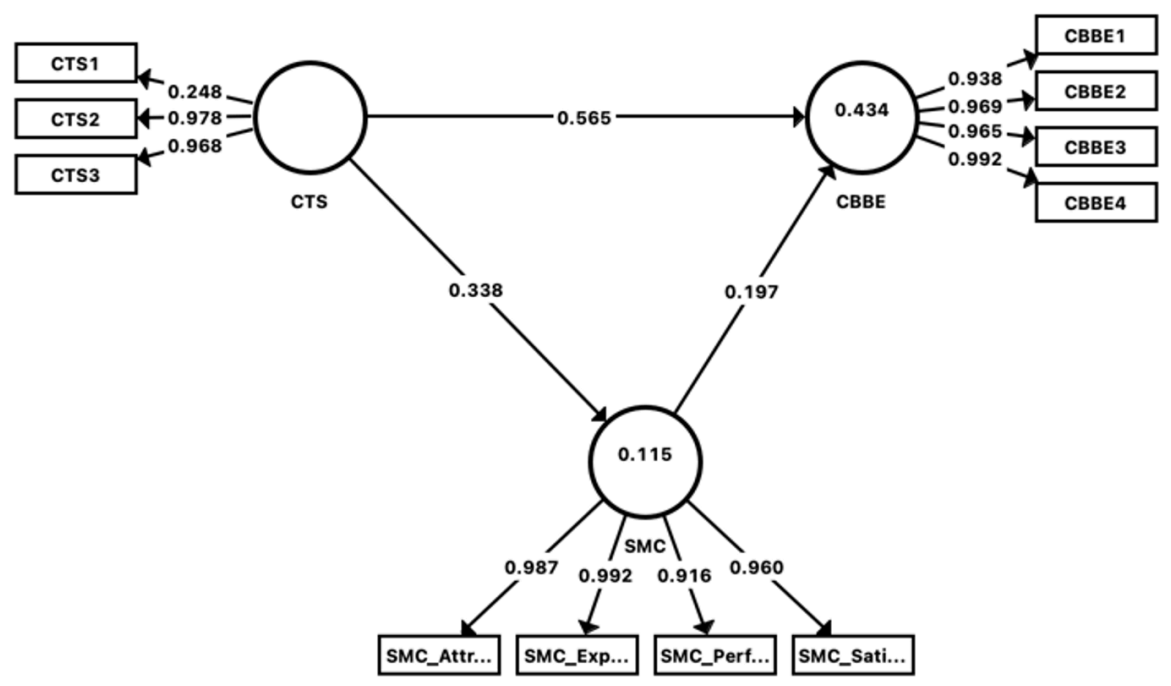

Figure 5. Multi-Group Model

\section{Discussion of Results}

To reassume the findings, table 10 exhibits the summary of hypothesis testing. The path coefficients, t-values and p-values allow us to accept three of the proposed eight hypotheses. The 'decision' column specifies if the hypothesis was supported or not supported.

Table 10. Summary of Hypothesis Testing

\begin{tabular}{|c|c|c|c|c|c|}
\hline & Relationship & Path Coefficient & $t$-value & p-value & Decision \\
\hline $\mathrm{H} 1$ & CTS $->$ CBBE & 0.577 & 8.913 & 0.000 & Supported \\
\hline $\mathrm{H} 2$ & CTS $->$ SMC & 0.227 & 2.063 & 0.039 & Supported \\
\hline $\mathrm{H} 3$ & $\mathrm{SMC} \rightarrow \mathrm{CBBE}$ & 0.009 & 0.102 & 0.918 & Not Supported \\
\hline & & $\begin{array}{c}\text { Path } \\
\text { Coefficients-diff }\end{array}$ & $\begin{array}{l}\mathrm{p} \text {-Value original } \\
\text { 1-tailed }\end{array}$ & $\begin{array}{c}p \text {-Value } \\
\text { new }\end{array}$ & \\
\hline $\mathrm{H} 4$ & $\begin{array}{l}\text { SMC -> CBBE (social media use in } \\
\text { pandemic) }\end{array}$ & 0.188 & 0.321 & 0.035 & Supported \\
\hline
\end{tabular}

In accordance with the results, the strongest and the most significant relation was observed between CTS and CBBE (path coefficient $=0.577$, $\mathrm{t}$-value $=8.913$, $\mathrm{p}$-value $<0.005$ ). It was not possible to prove the relationship of SMC with CBBE (t-value $<1.387$ and p-value $>0.05$ ). Interestingly, this relationship was proven to exist for the respondents who admitted using social media during pandemic more frequently.

Based on the results of the empirical study, it was confirmed that customer technological savviness has an influence on both the customer social media communication as well, as on the costumer perception of brand equity, which goes in pair with the previous postulates (e.g., Macdonald \& Uncles, 2007). Additionally, the results of the multi-group analysis indicated a relationship between user social media communication and the perceived brand equity in the case of customers 
who made a heavier use of social media during the pandemic. That goes in pair with Menon's (2017) postulates that "customers who use social media regularly, will place more weight on the opinions of people with similar views and thus will likely exhibit a greater response to firmgenerated content and messages by other customers, in the social media community" (p. 49).

\section{Conclusions}

This study fulfils its main objective and adds to the literature of branding and information technology management by investigating the customer behaviour in the times of pandemic, with a special attention on firm's social media communication, customer technology savviness and customer brand equity. The results of this study support Fishbein's (1979) theory of reasoned action, predicting the behaviour influenced by a specific situation. Also, as most of the participants of the empirical study belonged to the Net generation, this study gives some insights about their behaviour and perceptions, relating in this way to generational cohort theory.

Answering the questions leading this research. Firstly, considering the effect of customer technological savviness on customer perception of brand equity, the results of this study confirm that customer technology savviness has a strong and positive influence on customer perception of brand equity. That might be explained by the brand knowledge that the savvier customers might possess, and which is crucial for the positive brand equity (as postulated by Keller, 1993). Customers' tech savviness shows also to have an influence on their satisfaction with firm's social media communication. Those findings go in pair with Menon's (2017) and Kumar's et al. (2016) postulates. Interestingly, the results of this study do not support the relationship between the customer satisfaction with firm's social media communication and customer-based brand equity for the customers who have not experienced any behavioural change as the result of pandemic. This luck of support is an interesting finding as most of the literature nowadays indicates the opposite (e.g., Algharabat et al., 2019, Balakrishnan et al., 2014)). That however could be explained by the poorly designed communication, luck of content, or a passive approach that the firms have on social media and which intends only to 'look and observe' (as postulated by Constantinides, 2014). Finally, answering the last question of this investigation and considering the changes in the customer behaviour and attitudes caused by COVID-19 pandemic based on a multi-group analysis, the results were the most interesting and contradicted in some way what we had observed before. The multi-group analysis in which we have considered the raise in use of social media during the pandemic, the preference to shop online, as well as a changed view as it comes to a chosen brand, has revealed that the customer brand equity is influenced by the firm's social media communication which goes in pair with the previous Menon (2017) postulated.

Those are interesting findings both for practitioners as well as for academics. Indeed, the ongoing pandemic caused a change in customer behaviour and an increase in the use of new communication tools (e.g., Seth, 2020). As those changes are expected to last, we may presume that the social media communication will experience further growth and is crucial to consider while designing the customer branding campaigns. Additionally, the customers empowered with those new experiences probably will become even more technologically savvy. We might risk saying, that the COVID-19 pandemic will leave a deep mark and influence the years to come. 
The limitations of this study bring some suggestions for the future. As the sample was limited to respondents from Portugal (and mainly students), it would be interesting to replicate the study in different countries that have experienced different restrictions during the pandemic. Also, it could be interesting to see if those changes were greater in case of students and the part of population who shifted to work online. It might be possible that, after months of online working and studying experience, customers are indeed more technologically savvy but give less attention to social communication, craving for more personal human contact. Also, as the questionnaire focused on brands related to electronics and technology, which naturally generate more attention from tech savvy customers, it would be interesting to investigate different brands and different sectors. Finally, this study has only proposed to measure the behavioural change caused by the pandemic. It would be important also to consider if customers are indeed buying more online, or what is their level of trust in social media. The proposed measure of behavioural change should use 7-point Likert scale (as suggested by Cicchetti et al., 1985) and undergo a validation process. Also, as considering generational cohorts, it would be interesting to compare the different generations and their self-assessment of technological or net skills. Finally, the further studies should consider the outcomes of customer brand equity (identified in the first figure of this paper): repeat purchase, willingness to pay price premium, positive WOM or customer loyalty. It would be very interesting to see if they are influenced by tech savviness and social media communication.

\section{References}

Aaker, David A. (1991), Managing brand equity. Free Press.

Alam, M. S., \& Khan, B. M. (2019). The role of social media communication in brand equity creation: An empirical study. IUP Journal of Brand Management, 16(1), 54-78.

Algharabat, R., Rana, N. P., Alalwan, A. A., Baabdullah, A., \& Gupta, A. (2020). Investigating the antecedents of customer brand engagement and consumer-based brand equity in social media. Journal of Retailing and Consumer Services, 53, 1-13.

Balakrishnan, B. K., Dahnil, M. I., \& Yi, W. J. (2014). The impact of social media marketing medium toward purchase intention and brand loyalty among generation Y. Procedia-Social and Behavioral Sciences, 148, 177-185.

Bak-Coleman, J. B., Alfano, M., Barfuss, W., Bergstrom, C. T., Centeno, M. A., Couzin, I. D., ... \& Weber, E. U. (2021). Stewardship of global collective behavior. Proceedings of the National Academy of Sciences, 118(27). https://www.pnas.org/content/118/27/e2025764118

Benthaus, J., Risius, M., \& Beck, R. (2016). Social media management strategies for organizational impression management and their effect on public perception. Journal of Strategic Information Systems, 25, 127-139.

Bhattacharya, S., Mishra, B. B., \& Mishra, U. S. (2015). Impact of cyber atmospherics on buyers of different e-retailing sites: Literature review and conceptual model proposal.

Mediterranean Journal of Social Sciences, 6(6), 260-260. 
Bhattacharya, S., \& Singh, S. (2020). Visible insights of the invisible pandemic: A scientometric, altmetric and topic trend analysis. arXiv preprint arXiv:2004.10878. https://arxiv.org/pdf/2004.10878.pdf

Bishop, M. (2019). Healthcare social media for consumer informatics. In Consumer informatics and digital health (pp. 61-86). Springer, Cham.

Bruhn, M., Schoenmueller, V., \& Schäfer, D. B. (2012). Are social media replacing traditional media in terms of brand equity creation? Management Research Review, 35(9), 770-790.

Chin, W. W. (1998). The partial least squares approach to structural equation modeling. Modern Methods for Business Research, 295(2), 295-336.

Chin, W. W. (2010). How to write up and report PLS analyses. In Handbook of partial least squares (pp. 655-690). Springer, Berlin, Heidelberg.

Cicchetti, D.V., Showalter, D., \& Tyrer, P. J. (1985). The effect of number of rating scale categories on levels of interrater reliability: A monte carlo investigation. Applied Psychological Measurement, 9(1), 31-36.

Combes, B. (2021, March). The net generation: Tech-savvy or lost in virtual space? Proceedings of the IASL Annual Conference.

Colicev, A., Kumar, A., \& O'Connor, P. (2019). Modeling the relationship between firm and user generated content and the stages of the marketing funel. International Journal of Research in Marketing, 36(1), 100-116.

Constantinides, E. (2014). Foundations of social media. Procedia - Social and Behavioral Sciences, $148,40-57$.

Datta, H., Ailawadi, K. L., \& van Heerde, H. J. (2017). How well does consumer-based brand equity algin with sales-based brand equity and marketing-mix response? Journal of Marketing, 81(3), 1-20.

Donthu, N., \& Gustafsson, A. (2020). Effects of COVID-19 on business and research. Journal of Business Research, 117, 284-289. https://www.ncbi.nlm.nih.gov/pmc/articles/ $\underline{\mathrm{PMC} 7280091 /}$

Duffett, R. G. (2017). Influence of social media marketing communications on young consumers' attitudes. Young Consumers, 18(1), 19-39.

Eger, L., Komárková, L., Egerová, D., \& Mičík, M. (2021). The effect of COVID-19 on consumer shopping behaviour: Generational cohort perspective. Journal of Retailing and Consumer Services, 61, 102542. https://doi.org/10.1016/j.jretconser.2021.102542

Farquhar, P. H. (1989). Managing brand equity. Marketing Research, 1(3), 24-33.

Fishbein, M. (1979). A theory of reasoned action: Some applications and implications. Nebraska Symposium on Motivation, 27, 65-116.

Fornell, C., \& Larcker, D. F. (1981). Evaluating structural equation models with unobservable variables and measurement error. Journal of Marketing Research, 18(1), 39-50. 
Gefen, D., Straub, D., \& Boudreau, M. C. (2000). Structural equation modeling and regression: Guidelines for research practice. Communications of the Aassociation for Information Systems, 4(7), 2-79. http://www.dina.com.cn/news/UploadFiles/t10.pdf

Ginsberg, J., Mohebbi, M. H., Patel, R. S., Brammer, L., Smolinski, M. S., \& Brilliant, L. (2009). Detecting influenza epidemics using search engine query data. Nature, 457(7232), 1012-1014.

Goh, K., Heng, C., \& Lin, Z. (2013). Social media brand community and consumer behavior: Quantifying the relative impact of user- and marketer-generated content. Information Systems Research, 24(1), 88-107.

Hair Jr, J. F., Sarstedt, M., Hopkins, L., \& Kuppelwieser, V. G. (2014). Partial least squares structural equation modeling (PLS-SEM): An emerging tool in business research. European Business Review, 26(2), 106-121.

Hale, J. L., Householder, B. J., \& Greene, K. L. (2002). The theory of reasoned action. The Persuasion Handbook: Developments in Theory and Practice, 14, 259-286.

Hemlin, S., Allwood, C. M., Martin, B. and Mumford, M. D. (2014). Creativity and leadership in science, technology, and innovation. Routledge.

Henseler, J., Dijkstra, T. K., Sarstedt, M., Ringle, C. M., Diamantopoulos, A., Straub, D. W., ... \& Calantone, R. J. (2014). Common beliefs and reality about PLS: Comments on Rönkkö and Evermann (2013). Organizational Research Methods, 17(2), 182-209.

Ioanăs, E., \& Stoica, I. (2014). Social media and its impact on consumers behavior. International Journal of Economic Practices and Theories, 4(2), 295-303.

Jalilvand, M. R., \& Samiei, N. (2012). The impact of electronic word of mouth on a tourism destination choice. Internet Research, 22(5), 591-612.

Jayasuriya, N. A., Azam, S. M., Khatibi, A., Atan, H., \& Dharmaratne, I. R. (2018). The role of social media marketing research on brand equity - a literature review. Global Journal of Management and Buisness Research, 18(5), 31-39.

Jisana, T. K. (2014). Consumer behaviour models: An overview. Sai Om Journal of Commerce \& Management, 1(5), 34-43.

Judd, T. (2018). The rise and fall (?) of the digital natives. Australasian Journal of Educational Technology, 34(5), 99-119.

Jun, S. P., Yoo, H. S., \& Choi, S. (2018). Ten years of research change using Google Trends: From the perspective of big data utilizations and applications. Technological Forecasting and Social Change, 130, 69-87.

Kaplan, A. M., \& Haenlein, M. (2010). Users of the world, unite! The challenges and opportunities of social media. Business Horizons, 53(1), 59-68.

Keller, K. L. (1993). Conceptualizing, measuring, and managing customer-based brand equity. Journal of Marketing, 57(1), 1-22. 
Keller, K. L. (2016). Reflections on customer-based brand equity: perspectives, progress, and priorities. AMS Review, 6(1), 1-16.

Khadim, R. A., Zafar, B., \& Younis, M. (2014). Social media communication and consumer brand perceptions. International Journal of Social Sciences and Management Studies, 1(1), 12-20.

Kim, J. (2012). The institutionalization of YouTube: From user-generated content to professionally generated content. Media, Culture \& Society, 34(1), 53-67.

Kosic, M. (2018). Media literacy and for the net generation. International Journal of Emotional Education, 10(1), 68-88.

Kumar, A., Bezawada, R., Rishika, R., Janakiraman, R., \& Kannan, P. K. (2016). From social media to sale: The eddects of firm-generated content in social media on customer behavior. Journal of Marketing, 80(1), 7-25.

Lankshear, C., \& Knobel, M. (2007). Sampling "the new" in new literacies. A new literacies sampler, 29, 1-24.

Lebar, E., Buehler, P., Keller, K. L., Sawicka, M., Aksehirli, Z., \& Richey, K. (2005). Brand equity implications of joint branding programs. Journal of Advertising Research, 45(4), 413-425.

Lee, S. M., \& Chen, L. (2010). The impact of flow on online consumer behavior. Journal of Computer Information Systems, 50(4), 1-10.

Lorenzo, G., \& Dziuban, C. (2006). Ensuring the net generation is net savvy (pp. 290-310). Educause.

Macdonald, E. K., \& Uncles, M. D. (2007). Consumer savvy: Conceptualisation and measurement. Journal of Marketing Management, 23(5-6), 497-517.

Madden, T. J., Ellen, P. S., \& Ajzen, I. (1992). A comparison of the theory of planned behavior and the theory of reasoned action. Personality and Social Psychology Bulletin, 18(1), 3-9.

Malhotra, N., \& Birks, D. (2006). Marketing research: An applied perspective. Prentice Hall.

Menon, B. (2017). Determinants of online purchase intention, towards firm generated content in Facebook. International Journal Of Applied Marketing and Management, 2(2), 47-56.

Menon, B. (2018). Influence of customer tech savviness and proneness to social media, facilitating online purchase intention, supplemented through firms' content generation in Facebook. Drishtikon: A Management Journal, 9(1), 10-26.

Neti, P., Zhang, P., Qi, X., Zhou, Y., Younsi, K., Shah, M. R., \& Weeber, K. (2011, June). Online detection of endwinding contamination in industrial motors. Proceedings of the 2011 Electrical Insulation Conference (EIC). (pp. 265-270). IEEE.

Niu, Y., \& Wang, C. L. (2016). Revised unique selling proposition: Scale development, validation, and application. Journal of Promotion Management, 22(6), 874-896. 
Padayachee, K. (2017). The myths and realities of generational cohort theory on ICT integration in education: A South African perspective. The African Journal of Information Systems, $10(1), 4$.

Poulis, A., Rizomyliotis, I., \& Konstantoulaki, K. (2019). Do firms still need to be social? Firm generated content in social. Information Technology \& People, 32(2), 387-404.

Prensky, M. (2001). Digital natives, digital immigrants part 2: Do they really think differently? On the Horizon.

Ramya, N., \& Ali, M. (2016). Factors affecting consumer buying behavior. International Journal of Applied Research, 2(10), 76-80.

Rather, R. A. (2021). Monitoring the impacts of tourism-based social media, risk perception and fear on tourist's attitude and revisiting behaviour in the wake of COVID-19 pandemic. Current Issues in Tourism, 1-9. https://doi.org/10.1080/13683500.2021.1884666

Ryder, N. B. (1985). The cohort as a concept in the study of social change. In Cohort analysis in social research (pp. 9-44). Springer, New York, NY.

Schivinski, B., \& Dabrowski, D. (2014). The consumer-based brand equity inventory: Scale construct and validation (No. 4/2014 (22)). GUT FME Working Paper Series A.

Schivinski, B., Łukasik, P., \& Dabrowski, D. (2015). User-generated images and its impact on consumer-based brand equity and on purchase intention. Logistyka, (2), 1054-1061.

Schivinski, B., \& Dabrowski, D. (2016). The effect of social media communication on consumer perceptions of brands. Journal of Marketing Communications, 22(2), 189-

214. https://doi.org/10.1080/13527266.2013.871323

Seno, D., \& Lukas, B. A. (2007). The equity effect of product endorsement by celebrities: A conceptual framework from a co-branding perspective. European Journal of Marketing, 41(1/2), 121-134.

Sheth, J. (2020). Impact of Covid-19 on consumer behavior: Will the old habits return or die? Journal of Business Research, 117, 280-283.

Sullivan, D. (2016). Google now handles at least 2 trillion searches per year. Search Engine Land, 24. https://searchengineland.com/google-now-handles-2-999-trillion-searches-peryear- 250247

Tapscott, D. (1998). Growing up digital (Vol. 302). McGraw-Hill.

Tsimonis, G., \& Dimitriadis, S. (2014). Brand strategies in social media. Marketing Intelligence and Planning, 32(3), 328-344.

Turner, A. (2015). Generation Z: Technology and social interest. Journal of Individual Psychology, 71(2), 103-113.

Wan, F., \& Ren, F. (2017). The effect of firm marketing content on product sales: Evidence from a mobile social media platform. Journal of Electronic Commerce Research, 18(4), 288302. 
Weinberg, B. D., \& Pehlivan, E. (2011). Social spending: Managing the social media mix. Business Horizons, 54(3), 275-282.

Yadav, M., \& Rahman, Z. (2017). Measuring consumer perception of social media marketing activities in e-commerce industry: Scale development \& validation. Telematics and Informatics, 34(7), 1294-1307.

Yoo, B., Donthu, N., \& Lee, S. (2000). An examination of selected marketing mix elements and brand equity. Journal of the Academy of Marketing Science, 28(2), 195-211.

Zailskaitè-Jakštė, L., \& Kuvykaitè, R. (2016). Conceptualizing the social media communication impact on consumer based brand equity. Trends Economics and Management, 10(25), 6874.

\section{Authors Biographies}

Joanna K. Santiago, Ph.D. joined Universidade de Lisboa, ISEG - School of Economics and Management as an invited professor of Marketing and Strategic Marketing in September 2014. Later she has started lecturing Digital Marketing, Brand Management and CRM. She is also a lecturer of Strategic Management and Marketing Planning at VIVES University College, Belgium. She has a Ph.D. in Marketing and $\mathrm{MsC}$ in International Management and Marketing. Her research focuses on brand management, customer-based and employee-based perspective

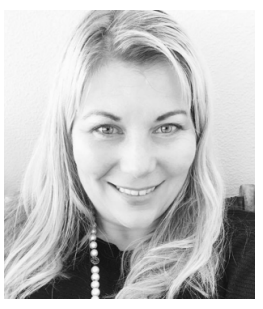
of brand equity, digital marketing and CRM. She has a solid background in market research and has participated in various research projects held at the top Portuguese schools of business and economics: Nova SBE, ISCTE, Catholic University and ISEG with the participation of Portuguese Foundation for Science and Technology (FCT), European Commission and Euromonitor International.

Miguel Pimenta, MS was awarded his Bachelor's Degree in Marketing and Advertising in 2018 and, at the beginning of 2021, he concluded his Master's Degree in Corporate Science at ISEG under the supervision of Prof. Joanna K. Santiago. The tech and automotive industries are what really fascinate him and take most of his time.

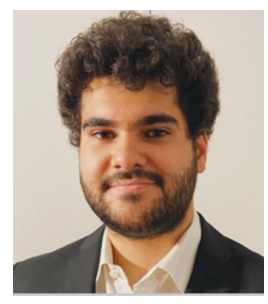


Appendix. Constructs and Measures Used in Quantitative Survey Instrument.

\begin{tabular}{|c|c|c|}
\hline Main Constructs & Item No. & Item Descriptions \\
\hline $\begin{array}{c}\text { Customer } \\
\text { Technology } \\
\text { Savviness (CTS) }\end{array}$ & $\begin{array}{l}\text { CTS1 } \\
\text { CTS2 } \\
\text { CTS3 }\end{array}$ & $\begin{array}{l}\text { I prefer to read information on the internet rather than in a brochure. } \\
\text { I am interested in new technology. } \\
\text { It is easy to locate the information I want on the internet. }\end{array}$ \\
\hline $\begin{array}{l}\text { Social Media } \\
\text { Communication } \\
\quad(\text { SMC) }\end{array}$ & $\begin{array}{l}\text { SMC_Satisfaction } \\
\text { SMC_Expectations } \\
\text { SMC_Attraction } \\
\text { SMC_Performance }\end{array}$ & $\begin{array}{l}\text { I am satisfied with the company's social media communications for [brand]. } \\
\text { The level of the company's social media communications for [brand] meets my } \\
\text { expectations. } \\
\text { The company's social media communications for [brand] are very attractive. } \\
\text { This company's social media communications for [brand] perform well, when } \\
\text { compared with the social media communications of other companies. }\end{array}$ \\
\hline $\begin{array}{l}\text { Consumer-Based } \\
\text { Brand Equity } \\
\text { (CBBE) }\end{array}$ & $\begin{array}{l}\text { CBBE1 } \\
\text { CBBE2 } \\
\text { CBBE3 } \\
\text { CBBE4 }\end{array}$ & $\begin{array}{l}\text { It makes sense to buy [brand] instead of any other brand, even if they are the same. } \\
\text { Even if another brand has the same feature as [brand], I would prefer to buy } \\
\text { [brand]. } \\
\text { If there is another brand as good as [brand], I prefer to buy [brand]. } \\
\text { If another brand is not different from [brand] in any way, it seems smarter to } \\
\text { purchase [brand]. }\end{array}$ \\
\hline $\begin{array}{l}\text { Confinement } \\
\text { Period Change }\end{array}$ & $\begin{array}{l}\text { CONF1 } \\
\text { CONF2 } \\
\text { CONF3 } \\
\text { CONF4 }\end{array}$ & $\begin{array}{l}\text { My view on [brand] changed during the confinement period. } \\
\text { My social media activity increased during the confinement period. } \\
\text { My online purchases increased during the confinement period. } \\
\text { Now I prefer to shop online. }\end{array}$ \\
\hline
\end{tabular}

